\title{
REHISTORICIZATION OF HISTORY, MELANCHOLY AND HATRED
}

\author{
Marcelo de Mello Rangel
}

For Hans Ulrich Gumbrecht

\begin{abstract}
We shall first discuss what we call a dehistoricization of history, that is, an obscuring of the possibility character of history which, if on the one hand, it can be understood from the very temporalization of history and also from a kind of tendency of men in general to the immediate continuation of the horizon within which they mobilize, on the other hand, it becomes dramatic throughout of modernity, from the generalization of the notion of progress. Then, in a second moment, we will work with the sentiments (Stimmungen) of melancholy, humor and hatred, and also with some skepticism, as being fundamental to the denial ofa certain "empathy" (Einfühlung), or even of an immediate relation uncritical with history. The fundamental thesis here is that all criticism and the very updating of what we call the character of possibility of history, as well as processes of equalization or justice, are marked by a certain impossibility, which makes necessary a sentimental economy adequate to recurrent insistence in these activities, and this in order to be possible, once again, the differentiation of history or its rehistoricization.
\end{abstract}

Key words: Walter Benjamin; Stimmung; Melancholy; History

\section{RE-HISTORICIZAÇ̃̃O DA HISTÓRIA, MELANCOLIA E HATRED}

\section{RESUMO}

Tematizaremos, num primeiro momento, especialmente a partir da tese IX das teses "Sobre o conceito de história", de Walter Benjamin, o que chamamos de uma deshistoricização da história, ou seja, de um obscurecimento do caráter de possibilidade da história o qual se, por um lado, pode ser compreendido a partir da própria temporalização da história e também a partir de uma espécie de tendência dos homens em geral à continuação imediata do horizonte no interior do qual se mobilizam, por outro lado, se torna dramático ao longo da modernidade, tendo em vista a generalização da noção de progresso. Em seguida, num segundo momento, trabalharemos com os sentimentos (Stimmungen) de melancolia, humor e ódio, e também com certo ceticismo, como sendo fundamentais à negação de determinada "empatia" (Einfühlung), ou ainda, de uma relação imediata, portanto a crítica com a história. A tese fundamental aqui é a de que toda crítica e a própria atualização do que chamamos de caráter de possibilidade da história, bem como processos de igualização ou de justiça, são marcados por certa impossibilidade, o que torna necessária certa economia sentimental que seja adequada à insistência

Professor of the Department of History and Postgraduate Programs in History and Philosophy of the Federal University of Ouro Preto (UFOP). Brazilian, resident in Ouro Preto - MG. Email: 
recorrente nessas atividades, e isto para que seja possível, uma vez mais, a diferenciação da história ou sua re-historicização.

Palavras-chave: Walter Benjamin; Stimmung; Melancolia; História

\section{Dehistoricization of history and melancholy}

One of the fundamental understandings of the theses On the Concept of History is that all and any historical horizon, when reorganized, is based on a process of generalization or transcendentalization, which is immediately reiterated by us all, while tending to forget its conjunctural (historical) character.In other words, whenever a horizon or epoch settles, we tend to forget that we are dealing with a time among other possible times.

In this sense, besides this more specifically ontological movement of the historical horizon, which when constituting itself obscures its character of possibility, we find also a more anthropological type of trend that collaborates with what would be an immediate identification or "empathy" (Einfühlung) with a certain state of affairs, with the order within which we move: a certain propensity for "sadness" ("acedia") or "conformism"1.

Thus, what is at issue here is that this immediate identification or "empathy" (Einfühlung) is sustained in what we could call an ontological determination, that is, in the actual way history mobilizes, and also in a reason that is more specifically anthropological. According to Benjamin, in a way, we are all exposed to certain type of "sadness" ("acedia"), which in turn tends to embrace that ontological determination, in such a way that while all and any historical horizon tends to obscure its character of possibility, we also tend to embrace it immediately - due to a tendency towards "conformism", apathy and discouragement - and to quickly echo its more general or common orientations. A "sadness" that Benjamin also called "idleness".

\footnotetext{
${ }^{1}$ Consult FREITAS, 2015.

Professor of the Department of History and Postgraduate Programs in History and Philosophy of the Federal University of Ouro Preto (UFOP). Brazilian, resident in Ouro Preto - MG. Email: mmellorangel@yahoo.com.br
} 
In this regard, what is at issue and what is fundamental to our text is precisely the understanding that there is a significant propensity to forget the character of historicity or possibility (reorganization or differentiation) of history and, therefore, a tendency towards a simple lasting repetition of a specific horizon, order or aspect.

There is also another element which, according to Benjamin, became fundamental in forgetting the character of historicity or the possibility of history, and also the actual role of man as a space or activity vital to any transformation or differentiation, namely the notion of progress. Progress is understood here as a strategy suited to a large portion of the philosophies of history and historicisms throughout the eighteenth and nineteenth century, which deals with history as if it mobilized towards a perfectible manifestation. Or perhaps, what is at issue here, based on this perception that history is univocal and perfectible, is precisely the obscuration of its character of historicity or possibility - its dehistoricization-, based on or together with the refusal of man's fundamental role in what would be his movement of differentiation.

Together with this Benjaminian description that indicates a difficulty regarding the reorganization or differentiation of history - its Rehistoricization-, especially in modern times, we begin to realize that the Theses, and not only them, but a great part of the texts published after 1935, such as "The Storyteller: Reflections on the Works of Nikolai Leskov" (Der Erzähler, published in 1936) and "Eduard Fuchs, collector and historian" (Eduard Fuchs, der Sammler und der Historiker, published in 1937), carry a melancholic tone or Stimmung, that is, an autonomous critical mobility in relation to any optimism and in spite of the very possibility of success. Therefore, it is, as I have come to see it, an activity that is constituted by the responsibility of a certain task. ${ }^{2}$

\footnotetext{
2 Benjamin's biography can also help us in the constitution and thematization of the hypothesis that the texts published after 1934 shifted from a more confident and optimistic tone (Stimmung) - as sustained by “Experience and poverty"(Erfahrung und Armut), published in 1933 -to a more affectionate and melancholic tone. In 1934, his lover, AsjaLācis, was imprisoned in Stalinist concentration camps and, in 1939, the Nazi-Soviet pact was signed, which Benjamin saw as a decisive victory for totalitarianism. See RANGEL, chapter 1, 2015.
}

Professor of the Department of History and Postgraduate Programs in History and Philosophy of the Federal University of Ouro Preto (UFOP). Brazilian, resident in Ouro Preto - MG. Email: mmellorangel@yahoo.com.br 
In regard to this melancholic critique by Benjamin, I like to describe, at least, part of the thesis that is probably the most famous, thesis IX. Benjamin starts his thesis with a quotation by his friend, Gershom Scholem, a GermanJewish historian and theologian, in which an angel affirmed that his wings were ready to take flight into the past, since the present was at risk. The quotation alludes to something terrible that would take form throughout modernity: forgetting the character of historicity or the possibility of history (the danger of its dehistoricization). In this sense, one would have to have the ability to delve into or even broach the past, making it possible to witness or recollect the character of the possibility of history and also the important role man would play in this movement of differentiation ${ }^{3}$; a thematization or investigation in the sense of making it explicit that the notion of progress, so dear to totalitarianisms in general, was just one among other possible temporal strategies, for example.

What is at issue here for Scholem - and for Benjamin - is that the notion of progress would have denied 1- the character of possibility of history, that all and any conjuncture is determined from a given dispute and superimposition, and further, 2- that men are important to its differentiation, and that a specific group of men, especially those involved with totalitarianisms, would be able to convince many people that their own activity would be responsible for accelerating the materialization of that which is progress, or perhaps, of the mobilization of humanity in a drive towards perfectibility or even perfection.

After the quotation by Scholem, Benjamin describes the painting Angelus Novus by his friend, Swiss German painter Paul Klee. As will be seen, and different from Scholem, Benjamin's positioncarries a rather melancholic tone. There is an angel on the painting, the angel of history, who looks towards the past, at which "he stares". But how can we describe his eyes? Different from the serene countenance of Scholem's angel with his "... wing(s) ready for a flight" and that would happily turn back ("I'm all for turning back", Benjamin, Thesis IX, p. 60), the eyes of Benjamin's angel are "wide-open", his mouth gapes, "opens"...

\footnotetext{
${ }^{3}$ Consult the discussion by Foucault on the problems of genealogy and of history, especially from the notion of emergency (Entstehung) in "Nietzsche, Genealogy, History", 1977.

Professor of the Department of History and Postgraduate Programs in History and Philosophy of the Federal University of Ouro Preto (UFOP). Brazilian, resident in Ouro Preto - MG. Email: mmellorangel@yahoo.com.br
} 
he is terrified and his wings are "spread"... different from Scholem's angel, which confidently asserts - "My wing is ready for a flight"! (Benjamin, Thesis IX, p. 60)

The wings of Benjamin's angel are "spread", tired, exhausted, because he has striven insistently to broach the past, hoping to surprise and witness the decisive moment (Entstehung, "emergency") from which this perspective of what constitutes progress can be generalized, thereby aiming to reveal its character of historicity, that it is simply one of the many available ways to understand that history is marked by what we call possibility and that every epoch or aspect is constituted from the tension rising from among a specific set of perspectives that, at some point, establish a hierarchical aspect based on a certain protagonism.

As previously highlighted, what is at issue in the movement of Scholem's and Benjamin's angel is the revelation of the mythical character of the foundation of the notion of progress, so dear to totalitarianisms in general, the mythical character of what would be its (and of all and any) transhistorical and necessary constitution. Benjamin highlights that, from then on, when looking at the past, the angel of history is horrified and exhausted because, while most men see progress, what he sees ahead is "one single catastrophe which keeps piling wreckage upon wreckage and hurls it at his feet". (Benjamin, Thesis IX, 62)

Benjamin's angel, like Scholem's (who would like to turn back...), would also "like to stay, awaken the dead, and make whole what has been smashed" (Benjamin, Thesis IX, 62). But this is not possible anymore! It is not possible, since it is no longer a question of goodwill (on the part of Scholem's angel), it is really the impossibility of that flight into the past and, by extension, of the difficulty itself of witnessing and remembering the character of historicity of all or any horizon or perspective - especially in regard to the understanding of progress. This flight into the past is impossible precisely because the strategy of progress would have sufficiently denied the character of possibility of history and obscured the important position of man in respect to his differentiation, provoking what we call a possible dehistoricization of history.

Totalitarianisms - from the generalization of the strategy of progress would be producing such a destructive energy that the angel of history would also 
be surprised by it. This energy would twist and entangle its wings, making it impossible to fly over the past, repelling it towards a future that would most likely be the space of destruction of humanity in general. Therefore, I wonder if not even the dead would be safe in a temporality like this and/or like ours (Benjamin, Thesis VI, 42), which we can easily understand after the fire and destruction of the National Museum in Rio de Janeiro recently. Perhaps, not even the angels were safe, according to Benjamin, and this is because they would be exhausted and their wings tied and even wounded. Thus, it would be or still is a "shipwreck without spectator" (Paolo Rossi, 1995). It is worth noting that Benjamin's understanding is not isolated or even exotic, it is an argumentation and even a generational Stimmung, as we can observe in Heidegger'sexpression the "escape of the gods", which refers to a very similar context, from the notion of technique ${ }^{4}$.

And Benjamin continues saying that a storm is blowing from the past:

"... and has got caught in his wings; it is so strong that the angel can no longer close them. This storm drives him irresistibly into the future, to which his back is turned, while the pile of debris before him grows towards the sky. What we call progress is this storm". (Benjamin, Thesis IX, p.62)

\section{Melancholy, empathy and hatred}

In order to understand Benjaminian melancholy and its critical power, we must somehow briefly resume a tradition that thematized the problem of melancholy prior to Freud's definition. Despite certain possible interpretations of the problem of melancholy according to Freud, the version we have has become generalized and somehow denies the critical, resilient and creative character that is typical of the melancholic mobilization ${ }^{5}$. In general, what we understand by melancholy is

\footnotetext{
${ }^{4}$ In respect to what I am calling a more general or generational atmosphere or Stimmung, consult Gumbrecht, 2012. For the problem of technique, consult Heidegger, 2001, and Casanova, 2012.

${ }^{5}$ Consult Kehl, 2015.

Professor of the Department of History and Postgraduate Programs in History and Philosophy of the Federal University of Ouro Preto (UFOP). Brazilian, resident in Ouro Preto - MG. Email: mmellorangel@yahoo.com.br
} 
its opposition to what Freud called mourning and, if mourning is a kind of elaboration and even sublimation of the loss of the loved object, melancholy, on the other hand, is the definitive impossibility of this elaboration and, consequently, a state characterized by passivity.

On the other hand, since Aristotle, through Neoplatonism, the Renaissance and Romanticism, the melancholic also moves incessantly, oscillating between moments of greater and lesser activity - without any external reason, without any optimism, for example, in respect to what would result from the activity. What lies at the heart of this mobility or oscillation is a certain mistrust or even skepticism in relation to what the actual melancholic person thinks and elaborates and also in relation to what is said in general, to what is common. Here, it is also worth emphasizing this kind of propensity that the melancholic person has regarding the activity of the imagination (or even fictional), in Kantian terms, which means concentrating on experiences that were not conceptually translated through understanding. Therefore, I would like to propose an understanding of this critical melancholic activity from: 1 - the oscillation between moments of greater and lesser activity, 2 - a specific skepticism, both in relation to oneself and to the most common, which leads to 3 - a certain absence of an external objective to this action, which must be performed, and 4- from the imagination or "fictional," work, which is determined precisely by a certain propensity of the melancholic to devote oneself to those experiences which were no longer properly translated through understanding, producing, from then on, images that would be sufficient and even specific to understand (and even modalize) the actual reality (Wirklichkeit) within which it is embedded 6 .

${ }^{6}$ In respect to the activity of imagination, consult Costa Lima, 2017, pp. 59-124. In this sense, Agamben argues that the object that may seem lost - and that would provoke the melancholic activity through a certain Freudian version or interpretation -, would instead be a kind of image that would make it seem lost, when, in fact, it is inappropriablein the horizon of the real (Wirklichkeit). Therefore, it is much more of a trick and something staged that would make this mobility and uncommon game possible, through which the real and transcendent object appear lost - , with which there is a certain intimacy. The melancholic would constitute a space within which it would be possible to: 1 - mobilize as if there had been a more intimate relation with a certain object, and 2- in this scope, constituted from this "as if" it would be possible to have what Agamben calls a or "some" "appropriation". Consult Agamben, 2007.

Professor of the Department of History and Postgraduate Programs in History and Philosophy of the Federal University of Ouro Preto (UFOP). Brazilian, resident in Ouro Preto - MG. Email: mmellorangel@yahoo.com.br 
This mobilization makes a series of questions possible, along with meaningful care, attention and concentration, especially in relation to dimensions of experience and reality (Wirklichkeit) that are not exactly evident, so that the melancholic activity becomes a space from which something unusual may appears, a forceful criticism, for example, that points to what has not yet been noticed.

Thus, when I work with the idea that Benjamin mobilizes within an emotional tone or melancholic Stimmung, especially in the texts published after 1935 and, more conclusively, in the Theses, I want to highlight that Benjamin's criticism of the denial of the character of possibility of history, and also of the fundamental role of man in regard to any differentiation of history, is: 1- baseless, that is, it is constituted in spite of any optimism regarding its generalization or achievement, and 2- that the melancholic critique - as it distrusts itself and the common, and is carefully dedicated to the understanding of reality (Wirklichkeit) through imagination - is capable of allowing less evident experiences to arise or, according to Benjamin's language, "voices" that at some point were denied ("defeated") and which can be heard through the space of imagination7. This, in turn, creates the possibility of what we are calling a rehistoricization of history.

In this regard, I really like two books by Leandro Konder, one of which is about Benjamin and the other about Kafka. In these books, he points out that both Benjamin and Kafka, as they allowed themselves to be more skeptical, began to renounce certain commitments to themselves and also to their surroundings and the common, which makes their critique even more remarkable ${ }^{8}$.

Therefore, we have a kind of perfect fit between that difficulty specific to any attempt at the rehistoricization of history - in modernity and now - and this emotional tone (Stimmung) of melancholy. This is because melancholy is marked

\footnotetext{
${ }^{7}$ Considering that understanding is guided and also determines a set of meanings, senses and feelings (Stimmungen), which tend to be repeated, as described previously, overruling experiences and "voices" that constitute the space of imagination.

${ }^{8}$ Consult Konder 1967 and 1999. Regarding a more general history on the problem of melancholy, especially from the perspective I am focusing on here, consult Klibansky, Panofsky and Saxl, 1979. Further consult Starobinski, 1989 and 2012, and Costa Lima, 2017.
}

Professor of the Department of History and Postgraduate Programs in History and Philosophy of the Federal University of Ouro Preto (UFOP). Brazilian, resident in Ouro Preto - MG. Email: mmellorangel@yahoo.com.br 
by care and even modesty suited to and sufficient for the near impossibility of updating the character of the possibility of history (now).

The Theses - profoundly melancholic - are marked by a task that is not exactly one of "revolution", "equalization" or historical "justice"/"justification", but far more by the assumption of the (near) impossibility of updating the character of the possibility of history and, therefore, by a very specific effort and preoccupation in regard to the (gratuitous) insistence in these tasks - that of "revolution", "equalization" and "justice"/“justification".

In this sense, when reading the Theses, it is also necessary to take part in this melancholic atmosphere (Stimmung), that is, it is far more necessary to think and act gratuitously rather than act from any element extrinsic such as, for example, the hope, and this in a somewhat skeptical way, capable of lingering - straining, questioning and inquiring.

Thus, it is a critical activity, more attentive to what subsists (to what understanding has not translated), a patient and insistent critique that would be suited to any and all temporality, especially that of Benjamin and our own, too! Therefore, we would still be protected from a kind of pair constituted by optimism and pessimism (part of the logic of progress) ${ }^{9}$.

I have talked about the emotional tones (Stimmungen) of optimism and pessimism and to what degree I consider them inadequate in respect to temporalities in general, especially ours. I also have the impression that Benjamin makes an effort, in his Theses, to evidence the danger represented by optimism and, consequently, by pessimism ${ }^{10}$.

Optimism is inadequate to any and all temporality precisely because it tends towards a desire or expectation that, eventually, everything will unfold positively,

\footnotetext{
${ }_{9}^{9}$ About optimism and pessimism, consult Rangel 2019, pp. 87-112.

${ }^{10}$ Consult Thesis $\mathrm{X}, \mathrm{XI}$ and XII, which discuss the optimism of certain "social democracy" especially in respect to the possibility of the technique providing for the anticipation of man in relation to nature in a naive manner, considering that "social democracy", for example, has not been attentive to the radical inequality regarding the character of productive forces and also the relation of production.
}

Professor of the Department of History and Postgraduate Programs in History and Philosophy of the Federal University of Ouro Preto (UFOP). Brazilian, resident in Ouro Preto - MG. Email: mmellorangel@yahoo.com.br 
an expectation that contradicts the mobility of life, which, when mobilizing, often requires an exhaustive and painful activity from men in general. Optimism is certainly not suited to Benjamin's temporality, nor ours (which are similar in some ways!) since, in times that are marked by instability and the frenetic and inhumane pace of technique, in these critical times like ours, especially considering the uncertain/dangerous tension between the advance of the so called difference or democratization and the recomposition of rightism in the West in general (and in Brazil, especially), any enthusiastic - optimistic - expectation of a reasonable context is necessarily doomed to be frustrated time and again, until it becomes its perfect match: pessimism, apathy... and even authoritarian and fascist behavior, which we have looked at so closely ${ }^{11}$.

Considering the meaning of insistence on what would be the "revolution", "equalization", "justice" - historical "justification", or else, in respect to the persistence on the critique to modernity in the name of the differentiation of history, Benjamin thematizes a set of emotional tones which would be adequate to the suppression or even "destruction" of that relation of immediacy that we have, in general, with our historical horizon.

What happens is that there is a tendency for a kind of identification and immediate continuation of the transcendental horizon within which we move - a "empathy" (Einfühlung), and this due to the ontological tendency of obscuring the possibility character of history, and also to "sadness," "indolence," or "conformism" that would be proper to men in general - so that we would continue to behave theoretically and practically according to what is already established or common - which would be aggravated within modernity from the general understanding of progress. This "empathy" (Einfühlung) is thus intensified from the modern strategy of progress, which would work with the idea of a univocal

${ }^{11}$ Democratization as referred to in this text is very similar to the understanding of Jacques Rancière. It is about opening (and keeping) public space to tension. See Rancière, 2014.

Professor of the Department of History and Postgraduate Programs in History and Philosophy of the Federal University of Ouro Preto (UFOP). Brazilian, resident in Ouro Preto - MG. Email: mmellorangel@yahoo.com.br 
and perfectible history - hence, far from what would be its character of possibility - that would materialize despite human activity.

In this sense, in view of this immediate identification ("empathy", Einfühlung), any theoretical and practical movement dedicated to the recollection and updating of the character of possibility of history would be very difficult to be generalized. Thus, such a task would always have to be resumed ... "Every age must strive anew to wrest tradition away from the conformism that is working to overpower it...And this enemy has never ceased to be victorious." (Benjamin, Thesis $\mathrm{VI}, 42)$.

Having this understanding we are able to read Thesis IV, which begins with a quote from Hegel.

I always call the attention to the way Benjamin quotes texts, especially in Theses. He quotes texts and authors that are fundamental to his formation, among them Hegel, Nietzsche, Brecht and Scholem. But, he does not make these quotations because he wishes to justify or underline what he develops next. In cases such as these, in which he cites Hegel or Scholem, Benjamin presents lesser-known texts and passages, which generally point to different understandings of what the tradition generally makes stand out. What's more, beyond this interpretive inversion, he also builds his text rejecting some elements that he brings up in the quotes.

This is exactly what happens with regard to Hegel's quotation in Thesis IV. Hegel appears as a philosopher deeply concerned with what we call infrastructure, with the need for an effective equalization of what to "food and clothing". The idea of this passage is that - for Hegel - the constitution of an adequate superstructure, that is, of a state, laws, of an ideal thinking and of happiness itself would only be possible through this equalization (of infrastructure).

However, shortly after emphasizing this fairly singular reading of Hegel, Benjamin brings it closer to the Marxist tradition - so critical of Hegel - and questions both. Different from Hegel and the Marxists in general, most of whom were "schooled" (geschult) in Marx - that is, had read Marx in a faster and/or Professor of the Department of History and Postgraduate Programs in History and Philosophy of the Federal University of Ouro Preto (UFOP). Brazilian, resident in Ouro Preto - MG. Email: mmellorangel@yahoo.com.br 
programmatic manner - , Benjamin is mainly concerned with what would make possible the insistence on a struggle that would be very difficult, a struggle for a meaningful reorganization of history from what we call justice/justification and equalization.

It is in this sense that Benjamin thematizes the problem of emotional tones (Stimmungen) and their importance to insistence regarding the critical position emphasized previously. To him, prior to worrying about equalization or historical justice or justification, it is fundamental to be concerned with a certain sentimental economy (Stimmungen), which would sustain any and every struggle in the sense of differentiating the modern historical horizon; it would be fundamental, therefore, to cultivate feelings such as "confidence", "courage", "humor", "cunning", "steadfastness", and this because "...They constantly call into question every victory, past and present, of the rulers". (Benjamin, Thesis IV, 37)

I would like to highlight, at least briefly, the feelings of "humor" and "hatred", the latter which appears, in turn, in Thesis XII, when Benjamin states that "...the working class forgot both its hatred and its spirit of sacrifice."(Benjamin, Thesis XII, 78), and which seem to me fundamental in regard to the composition of this sentimental economy befitting the insistent questioning or denial of modernity and its radical inequality and injustice.

Regarding "humor", it is important to emphasize that it is a fundamental feeling or Stimmungof this more generalized emotional tone that is melancholy. Humor is a state of mind that is constituted precisely from that basic skepticism (and modesty) typical of Benjaminian melancholy. It is a kind of gesture that makes it possible to explain our fragility and finitude (underling it) with respect to criticizing modernity and reviving the character of possibility or differentiation of history. Humor is directly related to a certain ability to "laugh", even momentarily, at our fragility, in the sense of reproportioning it and minimizing the effects of despair, passivity, pessimism and even authoritarianism. In this sense, it is the very assumption of finitude and, thus, a reminder that it is necessary to be constantly attentive, because our "strength" in terms of the possible reorganizations of history, which Benjamin also calls "messianic force", is "weak "(schwach). (See Thesis II)

Professor of the Department of History and Postgraduate Programs in History and Philosophy of the Federal University of Ouro Preto (UFOP). Brazilian, resident in Ouro Preto - MG. Email: mmellorangel@yahoo.com.br 
Finally, the "hate". Benjamin argues that we need hatred as an emotional tone, precisely so that we can move away from "empathy" (Einfühlung) as much as possible, which tends to determine us due to the ontological mobilization of the story itself, and also from a kind of tendency towards "sadness" and "conformity", especially with regard to modernity, due to the generalized notion of progress, which has in a way guided many of us.

It would thus be necessary to cultivate a kind of antipathy (disinterest, "boredom") for all that exists, that is, for everything firmly established in our world, this being so because everything that has reached this more general or transcendental condition would have been either well constituted, "interpreted" or reoriented for the simple repetition of the profoundly unequal and unfair historical horizon that is modernity (and ours!), since "There is no document of culture which is not at the same time a document of barbarism." (Benjamin, Thesis VII, 47)

This "hatred" or antipathy towards the most fundamental meanings, senses and rhythms of our world would be the emotional tone (Simmung) that constitutes what Benjamin calls "history against the grain", or perhaps, all and any theoretical behavior that is also dedicated to listening, welcoming and reverberating denied and dissonant gestures and perspectives. However, unfortunately, we will not have time to delve deeper into this issue, this "hatred" or antipathy which, in turn, is based on another feeling or basic Stimmung, love (caritas). This is the love for the "vanquished", the "forgotten" or even those wronged from yesterday and today!

Professor of the Department of History and Postgraduate Programs in History and Philosophy of the Federal University of Ouro Preto (UFOP). Brazilian, resident in Ouro Preto - MG. Email: mmellorangel@yahoo.com.br 


\section{BIBLIOGRAPHY}

ABREU, Marcelo; RANGEL, Marcelo de Mello. Memória, culturahistórica e ensino de história. História e Cultura, v. 2, n. 4, set. 2015.

http://periodicos.franca.unesp.br/index.php/historiaecultura/article/view/1625

ARAUJO,Valdei Lopes de. História da historiografiacomoanalítica da historicidade. História da Historiografia: International journal of theory and history of historiography, v. 12, p. 34-44, 2013.https://www.historiadahistoriografia.com.br/revista/article/view/620

ARAUJO,Valdei Lopes de; RANGEL, Marcelo de Mello. Introduction - Theory and history of historiography: from the linguistic turn to the ethical-political turn. História da Historiografia: International journal of theory and history of historiography, n. 17, April, 2015, p. 333-346.

https://www.historiadahistoriografia.com.br/revista/article/view/928/550

AGAMBEN, Giorgio.Estâncias. A palavra e o fantasmanaculturaocidental. Belo Horizonte: Editora UFMG, 2007.

Infância e história. Destruição da experiência e origem da história. Belo Horizonte: Editora UFMG, 2005.

AMITRANO, Georgia Cristina. Força de lei: a força das palavras de Derrida napolítica de Agamben - encontros entre aarte e a política. In.: HADDOCKLOBO, Rafael; RODDRIGUES, Carla; SERRA, Alice; AMITRANO, Georgia; RODRIGUES, Fernando (Orgs.). Heranças de Derrida. Da linguagem à estética. v. 3. Rio de Janeiro: NAU, 2014.

ARISTÓTELES. O homem de gênio e a melancolia. Problema XXX,1. Rio de Janeiro: LacerdaEditores, 1998.

BARLETTA, Vincent. Rhythm as form. Dibur Literary Journal, Issue 2, Spring 2016.

BENJAMIN, Walter. On the concept of history. In. LÖWY, Michael.Fire alarm. Reading Walter Benjamin's 'On the concept of history'. Translation of Chris Turner. London; New York: Verso, 2005.

. Über den Begriff der Geschichte. Walter Benjamin

GesammelteSchriften, t.1 (2), p. 691-704. Frankfurt am Main: Suhrkamp, 1991.

BEVERNAGE, Berber. History, Memory and State-Sponsored Violence. New York: Routledge, 2012.

Professor of the Department of History and Postgraduate Programs in History and Philosophy of the Federal University of Ouro Preto (UFOP). Brazilian, resident in Ouro Preto - MG. Email: mmellorangel@yahoo.com.br 
CASANOVA, Marco Antonio. "O homementediado: niilismo e técnica no pensamento de Martin Heidegger". EKSTASIS: Revista de Hermenêutica e Fenomenologia, 2012.

CHAKRABARTY, Dipesh. Antropocene Time. History and Theory, n. 57, p. 532. 2018.

COSTA LIMA, Luiz. Melancolia: Literatura. São Paulo: Unesp, 2017.

DERRIDA, Jacques. Force de loi. Le Fondement mystique de l'autorité. Paris: Galilée, 1994.

DOMANSKA, Ewa. The material presence of the past. History and Theory, v. 45, p. 337-348, 2006.

Sincerity and the discourse of the past. Paper presented at the International Conference on the History and Theory of Historical Studies: Disciplines and Discourses. CEU, Budapest, October 21-24, 2004.

EILAND, Howard; JENNINGS, Michael W. Walter Benjamin. A critical life. Cambridge, Massachusetts; London, England, 2014.

FOGEL, Gilvan; RUIN, Hans; SCHUBACK, Márcia Sá Cavalcante. Por umafenomenologia do silêncio. Rio de Janeiro: SetteLetras, 1996.

FOUCAULT, Michel. Nietzsche, Genealogy, History. In. Language, CounterMemory, Practice: Selected Essays and interviews, edited by D. F. Bouchard. Ithaca: Cornell University Press, 1977.

FREITAS, Romero. Estranhamentoouempatia? Notassobre o problema do conhecimentohistóricoem Walter Benjamin. In.: IANNINI, Gilson; GARCIA, Douglas; FREITAS, Romero (Orgs.). Arte e Filosofia. Antologia de textosestéticos. Rio de Janeiro: CivilizaçãoBrasileira, 2015.

GAGNEBIN, Jean-Marie. Apagarosrastros, recolherosrestos. In.: SEDLMAYER, Sabrina; GUINZBURG, Jaime (Orgs.). Walter Benjamin. Rastro, aura e história. Belo Horizonte: Editora UFMG, 2012.

História e narraçãoem Walter Benjamin. São Paulo:

Perspectiva; FAPESP: Campinas, SP: Editora da Universidade Federal de Campinas, 1994.

Sete aulas sobrelinguagem, memória e história. Rio de Janeiro: Imago Ed. 1997.

GUMBRECHT, Hans Ulrich. Atmosphere, mood, Stimmung: On a hidden potential of literature. Stanford, California: Stanford University Press, 2012.

Benjamin-zwichenbilanznach dem zenit. Was

istalsPotenzialfuer die Zukunftgeblieben? (Unpublished)

GUMBRECHT, Hans Ulrich; MARRINAN, Michael. Mapping Benjamin. The work of art in the digital age. Stanford: Stanford University Press, 2003.

Professor of the Department of History and Postgraduate Programs in History and Philosophy of the Federal University of Ouro Preto (UFOP). Brazilian, resident in Ouro Preto - MG. Email: mmellorangel@yahoo.com.br 
HADDOCK-LOBO, Rafael. Para um pensamentoúmido. Rio de Janeiro: NAU: Ed. PUC-Rio, 2011.

. "Walter Benjamin e Michel Foucault: aimportânciaética do deslocamento para umaOutraHistória". RevistaComum, Rio de Janeiro, v. 9, n. 22, pp. 56-75, jan.-jun, 2004.

HEIDEGGER, Martin. Contribuições à filosofia. Do

acontecimentoapropriativo. Rio de Janeiro: ViaveritaEditora, 2015.

Ensaios e conferências. Petrópolis: EditoraVozes, 2001.

Sein und Zeit. Tübingen: Max Niemeyer Verlag, 2006.

KEHL, Maria Rita. A melancoliaem Walter Benjamin e em Freud. In.: MACHADO, Carlos Eduardo Jordão; MACHADO Jr. Rubens; VEDDA, Miguel (orgs.). Walter Benjamin. Experiênciahistórica e imagens dialéticas. São Paulo: EditoraUnesp. 2015.

KLEINBERG, Ethan. Hauting history: For a deconstructive approach to the past. Stanford, California: Stanford University Press, 2017.

Presence: Philosophy, Historyand Cultural Theory for theTwentyFirstCentury. Volume co-editedwithRanjanGhosh.Ithaca, New York: Cornell University Press, 2013.

KLIBANSKY, Raymond et al., Saturn and Melancholy: Studies in the History of Natural Philosophy, Religion, and Art. Nendeln: Kraus, 1979.

KONDER, Leandro. Kafka Vida e Obra. Rio de Janeiro: Jose Álvaro Editor, 1967.

. Walter Benjamin: O Marxismo da Melancolia. Rio de Janeiro:

CivilizaçãoBrasileira, 1999.

KOSELLECK, Reinhart. VergangeneZukunft.

ZurSemantikgechichtlicherZeiten. Frankfurt am Main: Suhrkamp, 1979.

MATOS, Olgária. Benjaminianas. Advinhas do tempo: êxtase e revolução. São Paulo: HUCITEC, 2008.

. Osarcanos do inteiramente outro. A Escola de Frankfurt. A melancolia e a revolução. São Paulo: Editora Brasiliense, 1989.

. O iluminismovisionário: Benjamin, leitor de Descartes e Kant. São Paulo: Brasiliense, 1999.

. "Pórticos e passagens: Walter Benjamin - contratempo e história". In.: MACHADO, Carlos Eduardo Jordão; MACHADO Jr. Rubens; VEDDA, Miguel (orgs.). Walter Benjamin. Experiênciahistórica e imagens dialéticas. São Paulo: EditoraUnesp. 2015.

. Walter Benjamin: pólisgrega, metrópolesmodernas. In.: JOBIM E SOUZA, Solange; KRAMER, Sonia (Orgs.). Política,cidade,educação.

Professor of the Department of History and Postgraduate Programs in History and Philosophy of the Federal University of Ouro Preto (UFOP). Brazilian, resident in Ouro Preto - MG. Email: mmellorangel@yahoo.com.br 
Itinerários de Walter Benjamin. Rio de Janeiro: Contraponto: Editora PUC-RIO, 2009.

NIETZSCHE, Friedrich. UnzeitgemässeBetrachtungen - ZweitesStück: VomNutzen und Nachtheil der Historiefür das Leben DTV/De Gruyter (Die Geburt der Tragödie - KritischeStudienausgabeHerausgegeben von Giorgio Colli und MazzinoMontinari) - KSA Volume 4.

PIHLAINEN, Kalle. On historical consciousness and popular pasts. História e Historiografia, v. 15, p. 10-26, 2014.

PINHO, Amon. "Da históriacomociência e como forma de rememoração: Construçãosalvadora e destruiçãoredentoraem Walter Benjamin".Cadernos Benjamin, v. 1, Julho a Dezembro de 2008.

RANCIÈRE, Jacques. Ódio à democracia. São Paulo: Boitempo, 2014.

RANGEL, Marcelo de Mello. Da ternura com o passado: História e pensamentohistoriconafilosofiacontemporânea. Rio de Janeiro: Via Verita, 2019.

. "História e Stimmung a partir de Walter Benjamin:

Sobrealgumaspossibilidadesético-políticas da historiografia". Cadernos Walter Benjamin, v. 17, 2016. http://www.gewebe.com.br/pdf/cad17/texto 10.pdf . Justiça e Históriaem Derrida e Benjamin. Sapere Aude, Belo Horizonte, v. 4, n. 7, 2013, pp. 347-359.

http://periodicos.pucminas.br/index.php/SapereAude/article/view/4929

"Melancolia e históriaem Walter Benjamin".

RevistaEnsaiosFilosóficos, v. XIV - Dezembro/2016.

http://www.ensaiosfilosoficos.com.br/Artigos/Artigo14/11 RANGEL Ensaios Fil osoficos Volume XIV.pdf

Modernidade e história a partir de Walter Benjamin e Derrida. Tese de doutoradodefendida no Programa de Pós-GraduaçãoemFilosofia (PPGF) da Universidade Federal do Rio de Janeiro (UFRJ), 2015.

Nietzsche e o pensamentohistorico: justiça, amor e felicidade.

RevistaTrágica: estudos de filosofia da imanência. Rio de Janeiro, vol. 10, $\mathrm{n}$.

2, p. 69-85, 2017. http://tragica.org/artigos/v10n2/4\%20-

$\% 20$ Marcelo\%20de\%20Mello\%20Rangel\%20-

\%20Nietzsche\%20e\%200\%20pensamento\%20histo\%CC\%81rico.pdf

. "Sobre a utilidade e desvantagem da ciênciahistórica, segundo

Nietzsche e Gumbrecht". RevistaDimensões, Universidade Federal do Espírito Santo (UFES), v. 24, 2010.

http://www.periodicos.ufes.br/dimensoes/article/view/2531/2027

REYES MATE. Medianoche en la historia. Comentarios a las tesis de Walter Benjamin 'Sobre el concepto de historia'”. Madrid: Editorial Trotta, 2006. 
RODRIGUES, Carla. Adorno e Derrida: um debate nacomunicação.

Emquestão, Porto Alegre, v. 18, n. 2, jul./dez. 2012, pp. 43-56.

RODRIGUES, Thamara de Oliveira.

Theoryofhistoryandhistoryofhistoriography:Openings for "unconventional histories". História da Historiografia: International journal of theory and history of historiography, v. 12, n. 29, p. 96-123, 2019.

https://www.historiadahistoriografia.com.br/revista/article/view/1303/787

ROSSI, Paolo. Naufragi senza spettatore. L'idea di progresso. Bologna: II Mulino, 1995.

SOLIS, Dirce Eleonora Nigro. Jacques Derrida e a freqüentação dos espectros. In.: HADDOCK-LOBO, Rafael; RODDRIGUES, Carla; SERRA, Alice; AMITRANO, Georgia; RODRIGUES, Fernando (Orgs.). Heranças de Derrida. Da linguagem à estética. Vol. 1. Rio de Janeiro: NAU, 2014.

SONTAG, Susan. Sob o Signo de Saturno. Porto Alegre: L\&PM, 1986.

STAROBINSKI, Jean. La mélancolie au mirror. Trois lectures de Baudelaire: Conferences, essays et leçons du Collège de France. Paris: Julliard, 1989.

. L’Encre de la mélancolie. Paris: Seuil, 2012.

WHITE, Hayden. The Practical Past. Evanston, Illinois: Northwestern University Press, 2014.

WITTE, Bernd. Walter Benjamin. Uma biografia. Tradução de Romero Freitas. Belo Horizonte: AutênticaEditora, 2017. 